\title{
Addition of L-arginine in skim milk extender maintains goat spermatozoa quality in chilled temperature for five days
}

\author{
Suherni Susilowati ${ }^{1}$, Indah Norma Triana ${ }^{1}$, Wurlina Wurlina ${ }^{1}$, Arimbi Arimbi ${ }^{2}$, Pudji Srianto ${ }^{1}$ and Imam Mustofa ${ }^{1}$ \\ 1. Department of Veterinary Reproduction, Faculty of Veterinary Medicine, Universitas Airlangga, Kampus C Unair, \\ Jl. Mulyorejo, Surabaya - 60115, Surabaya, Indonesia; 2. Department of Veterinary Pathology, Faculty of Veterinary \\ Medicine, Universitas Airlangga, Kampus C Unair, Jl. Mulyorejo, Surabaya - 60115, Surabaya, Indonesia. \\ Corresponding author: Imam Mustofa, e-mail: imam.mustofa@fkh.unair.ac.id \\ Co-authors: SS: suhernifkhunair@gmail.com, INT: indahnorma@gmail.com,WW: wurlina_made@yahoo.co.id, \\ AA: arimbi@fkh.unair.ac.id, PS: pudjisrianto@yahoo.com \\ Received: 29-07-2019, Accepted: 11-10-2019, Published online: 15-11-2019
}

doi: www.doi.org/10.14202/vetworld.2019.1784-1789 How to cite this article: Susilowati S, Triana IN, Wurlina W, Arimbi A, Srianto P, Mustofa I (2019) Addition of L-arginine in skim milk extender maintains goat spermatozoa quality in chilled temperature for five days, Veterinary World, 12(11):1784-1789.

\begin{abstract}
Aim: The purpose of this study was to determine the benefits of L-arginine addition in skim milk extender to maintain the quality of goat spermatozoa in chilled storage.

Materials and Methods: A total of 18 ejaculates from three healthy goats with weight and age of $45 \mathrm{~kg}$ and 4-5 years, respectively, were divided into three groups. The control group contained goat semen diluted in a skim milk extender without L-arginine; Treatment I and Treatment II contained goat semen diluted in a skim milk extender with added L-arginine 4 and $6 \mathrm{mM}$, respectively. These three groups were chilled at $5^{\circ} \mathrm{C}$ and evaluated daily for 5 days. Observed variables were viability, motility, intact plasma membrane (IPM), malondialdehyde (MDA) level, necrosis, and apoptosis of spermatozoa.

Results: The addition of L-arginine $4 \mathrm{mM}$ was the best treatment in maintaining viability, motility, and IPM and a decreased MDA level, percentage of necrosis, and apoptosis of goat spermatozoa. An ejaculate in this extender can be divided into 37 doses for intracervical insemination in $<1 \mathrm{ml}$ volume with 125 million motile spermatozoa.
\end{abstract}

Conclusion: Goat semen retained its quality when kept for 5 days in chilled storage by adding L-arginine in skim milk extender.

Keywords: apoptosis, goat spermatozoa, L-arginine, malondialdehyde level, necrosis.

\section{Introduction}

Etawa goat is a popular name in Indonesia for Jamnapari (or Jamunapari), a breed of goat originating from the Indian subcontinent. This breed is distributed almost all around the island of Java, Indonesia, for both milk and meat. The average age of first mating is 18 months, with conception rate at nearly $90 \%$ by natural mating, commonly resulting in triplet or quadruplet pregnancy. The average milk yield is almost 2 $\mathrm{kg} /$ day. With these advantages, Etawa goats are better bred by artificial insemination techniques than natural mating. Artificial insemination technology has been developed in Indonesia with excellent results, especially in cattle and dairy cows. However, the application of this technology in small ruminants is still minimal. In the future, artificial insemination will play an essential role in breeding programs of sheep or goats in Indonesia.

One contributing factor in the effort to optimize the program of artificial insemination in goats is the

Copyright: Susilowati, et al. Open Access. This article is distributed under the terms of the Creative Commons Attribution 4.0 International License (http://creativecommons.org/licenses/ by/4.0/), which permits unrestricted use, distribution, and reproduction in any medium, provided you give appropriate credit to the original author(s) and the source, provide a link to the Creative Commons license, and indicate if changes were made. The Creative Commons Public Domain Dedication waiver (http:// creativecommons.org/publicdomain/zero/1.0/) applies to the data made available in this article, unless otherwise stated. availability of frozen semen. However, the freezing process of goat spermatozoa causes more damage to membrane structure and function as well as the sperm's ability to sustain life [1]. Alternatively, artificial insemination in goats can be conducted using chilled semen. Semen is cooled to $5^{\circ} \mathrm{C}$ and stored for several days until it is used for insemination [2,3]. In bull semen, preservation at $5^{\circ} \mathrm{C}$ for $22 \mathrm{~h}$ results in a higher quality of postthawed sperm (motility, viability, and membrane integrity), and lower malondialdehyde (MDA) and DNA damage, compared to those of $4 \mathrm{~h}$ [4]. The problem is that the life span of the spermatozoa after ejaculation is only $8 \mathrm{~h}$ and is mediated by increasing concentration of lactic acid, a metabolic product of the spermatozoa itself, which causes lipid peroxidation $[5,6]$. L-arginine is an amino acid that plays a role as an antioxidant that produces nitric oxide (NO), thereby reducing sperm membrane lipid peroxidation.

Therefore, this study was conducted to determine the best dose of L-arginine addition in skim milk extender based on the viability, motility, intact plasma membrane (IPM), MDA level, necrosis, and apoptosis of goat sperm storage at $5^{\circ} \mathrm{C}$ in 5 days.

\section{Materials and Methods}

\section{Ethical approval}

This study is excerpted from the ethical clearance examination of the Animal Care and Use Committee 
because semen collection using artificial vagina does not affect the normal physiology of goat.

\section{Experimental animals}

The study was conducted in the Teaching Farm of Faculty Veterinary Medicine, Universitas Airlangga, located at Gresik District, East Java, Indonesia. A total of three Etawa goats were used for semen collection; the average weights and ages of the goats were $45 \mathrm{~kg}$ and 3-4 years old, respectively. Semen was collected from the goats 2 weeks after adaptation, 6 times for each goat, using an artificial vagina equipped with scaled glass containers. Immediately after collection, semen was brought to a laboratory to be examined macroscopically (volume, color, odor, consistency, and $\mathrm{pH}$ ) and microscopically (mass movement, individual movement, viability, concentration, and hypo-osmotic swelling [HOS] test).

\section{Skim milk extender}

Ten grams of skim milk was prepared, added to $100 \mathrm{ml}$ water, heated at $92-95^{\circ} \mathrm{C}$, then cooled to $20-27^{\circ} \mathrm{C}$. Added to this was $1000 \mathrm{IU} / \mathrm{ml}$ of penicillin and $1 \mathrm{mg} / \mathrm{ml}$ of streptomycin [7]. The ejaculate of each goat at every collection was divided into three parts of equal volume and diluted in extender for a final sperm concentration of 400 million sperm cells $/ \mathrm{ml}$. The control group (CG) consisted of extender (without L-arginine) + goat semen; Treatment I (T1) of extender + L-arginine $(4 \mathrm{mM})$ + goat semen; and Treatment II (T2) of extender + L-arginine $(6 \mathrm{mM})+$ goat semen. All three treatments were chilled at $5^{\circ} \mathrm{C}$ and evaluated for percentage of sperm viability, motility, intact of the plasma membrane, MDA level, necrosis, and apoptosis daily for 5 days.

\section{Examination of variable Viability}

Fresh semen was dropped on glass, eosin-negrosin was added, mixed homogeneously, and a smear preparation was made and dried over the flame quickly. The viability of the sperm was examined with a microscope $400 \times$. The percentage of dead and living spermatozoa was calculated in three microscopic fields of view. The assessment of spermatozoa viability was as follows: head of live spermatozoa appeared transparent or clear, meanwhile died spermatozoa suffered damage on the plasma membrane, caused increased permeability, dyes will enter the cell and head of spermatozoa look reddish [8].

\section{Motility}

A total of $10 \mu \mathrm{l}$ of semen suspension was added with $10 \mu \mathrm{l}$ of physiological $\mathrm{NaCl}$, homogenized and dripped on a glass object, then covered with a cover glass. Counted progressive (forward) moving of spermatozoa was conducted using a light microscope 400 times magnification [8]. Progressive motility of spermatozoa was determined in percentage.

\section{IPM}

The HOS test was used to evaluate plasma membrane integrity. As much as $1 \mathrm{ml}$ of hypoosmotic solution $\left(7.35 \mathrm{~g} \mathrm{Na}\right.$ citrate $2 \mathrm{H}_{2} \mathrm{O}, 13.52 \mathrm{~g}$ of fructose dissolved in $1000 \mathrm{ml}$ of aquades) was added with $0.1 \mathrm{ml}$ homogenized solution of diluted semen and then incubated at $37^{\circ} \mathrm{C}$ for $30 \mathrm{~min}$ and observed with a microscope $400 \times$. Spermatozoa with IPM are characterized by a coiled spermatozoa tail because the plasma membrane of spermatozoa still functions well in water absorption in hypotonic environments, while spermatozoa with damaged membranes are characterized by a straight tail [9].

\section{MDA}

The measurement of MDA levels (in $\mathrm{nmol} / \mathrm{ml}$ ) was carried out using the thiobarbiturate acid test method [5].

\section{Necrosis}

The necrotizing spermatozoa were characterized by pyknosis, karyorrhexis, and nucleus karyolysis, as identified using hematoxylin-eosin staining [10]. Necrosis sperm determined of 100 spermatozoa in five microscopic fields of view at $400 \times$ and presented in percentage.

\section{Apoptosis}

Examination of spermatozoa apoptosis used acridine orange staining. The spermatozoa preparations were first fixed with absolute methanol and glacial acid for $15 \mathrm{~min}$, stained with acridine orange, and then observed with a fluorescence microscope at $100 \times$. Spermatozoa with apoptosis were yellow to reddish, while the non-apoptotic ones were green [11].

\section{Statistical analysis}

Data were tabulated according to the observed variables. The result of viability, motility, IPM, MDA level, necrosis, and apoptotic sperm was subjected to ANOVA, and if there was a difference, it was followed with less significance difference test at $95 \%$ level of significance.

\section{Results}

This study used fresh goat semen, which was first examined macroscopically and microscopically. The macroscopic examination included volume, color, odor, consistency, and degree of acidity or $\mathrm{pH}$. The microscopic examination included mass movement, individual movement, concentration, and viability of the spermatozoa (Table-1).

Viability, motility, and dose for intracervical insemination

The addition of L-arginine in the milk extender produces a similar pattern of sperm viability and motility (Table-2). Semen extenders with the addition of L-arginine (T1 and T2) showed a higher $(\mathrm{p}<0.05)$ percentage of sperm viability and sperm motility compared to $C G$, either on the $1^{\text {st }}$ day until the $5^{\text {th }}$ day; the highest was in $\mathrm{T} 1$. 
Our field experience was using a dose of 125 million motile spermatozoa for intracervical insemination on goats and ewes. In this study, we could calculate the average of motile spermatozoa per ejaculation, i.e., the average of ejaculate volume (ml) multiply with spermatozoa concentration (million/ml) multiply with motility (\%). The number of intracervical insemination dose counted was based on the number of motile sperm divided by 125 million. Meanwhile, the volume of one dose for intracervical insemination was the volume of extended semen divide with the number of doses (Table-3). The supplementation of $4 \mathrm{mM}$ L-arginine in the skim milk extender (T1) had the highest motile spermatozoa, although, on the $5^{\text {th }}$ day of storage at $5^{\circ} \mathrm{C}$, it could be divided into 37 doses with $<1 \mathrm{ml}$ volume for intracervical insemination.

\section{Intact of the plasma membrane (IPM) and MDA}

The IPM and MDA level in this study is illustrated in Table-4. The additional $4 \mathrm{mM}$ of L-arginine (T1) in semen extenders showed the highest percentage of the

Table-1: Macroscopic and microscopic characteristics of fresh goat semen.

\begin{tabular}{lc}
\hline Indicators & Characteristics \\
\hline Color & White yellowish \\
Odor & Typical \\
Consistency & Thick \\
$\mathrm{pH}$ & 7.00 \\
Volume $(\mathrm{ml})$ & $2.5 \pm 0.35$ \\
Concentration (million/mm $\left.{ }^{3}\right)$ & $3995 \times 10^{6}$ \\
Mass motility & +++ \\
Individual motility $(\%)$ & Progressive $(85 \pm 3.50)$ \\
Viability $(\%)$ & $91 \pm 2.45$ \\
Intact plasma membrane $(\%)$ & $82 \pm 1.55$ \\
\hline
\end{tabular}

IPM, and lowest MDA level, either on days 1, 2, 3, 4, and $5(\mathrm{p}<0.05)$ compared to $\mathrm{CG}$ and $\mathrm{T} 2$.

\section{Necrosis and apoptosis}

Diluted semen without the addition of L-arginine (CG) showed the highest percentage of necrosis and apoptosis of spermatozoa in all days of study, followed by $\mathrm{T} 2$, and the lowest was $\mathrm{T} 1(\mathrm{p}<0.05)($ Table-5).

\section{Discussion}

The fresh goat semen in this study has been qualified to be processed for artificial insemination use by diluting semen based on ejaculate volume and percentage of motility (Table-1). In goats with an ejaculate volume of more than $0.5 \mathrm{ml}$ and motility of more than $70 \%$ can be used for artificial insemination with fresh or diluted semen. Decreased spermatozoa fertility will occur depending on the length of storage [12].

\section{Viability, motility, and dose for intracervical insemination}

The high motility of spermatozoa requires high energy derived from mitochondrial metabolism, which results in the high level of reactive oxygen species (ROS) that harms spermatozoa viability. The small volume of sperm cytoplasm makes it challenging to transport antioxidant enzymes, such as glutathione peroxidase, catalase, and superoxide dismutase into other compartments in the spermatozoon to address ROS [13].

Spermatozoa metabolism increases with the presence of L-arginine [14]. L-arginine increases $\mathrm{NO}$ in cells that are synthesized by NO synthases, an isoenzyme family in mitochondria [15]. NO plays a

Table-2: Effect of L-arginine addition in skim milk extender and chilled for 5 days evaluation on viability and motility (\%) of goat spermatozoa.

\begin{tabular}{lccccc}
\hline Parameters & Day 1 & Da y 2 & Day 3 & Day 4 & Day 5 \\
\hline Viability & & & & & \\
CG & $80.40 \pm 2.08^{\mathrm{c}}$ & $68.17 \pm 4.49^{\mathrm{c}}$ & $50.50 \pm 2.24^{\mathrm{c}}$ & $41.50 \pm 3.24^{\mathrm{c}}$ & $39.33 \pm 2.50^{\mathrm{c}}$ \\
T1 & $89.33 \pm 1.45^{\mathrm{a}}$ & $79.83 \pm 4.23^{\mathrm{a}}$ & $70.83 \pm 2.22^{\mathrm{a}}$ & $58.51 \pm 3.08^{\mathrm{a}}$ & $47.83 \pm 3.08^{\mathrm{a}}$ \\
T2 & $82.50 \pm 2.17^{\mathrm{b}}$ & $76.50 \pm 2.50^{\mathrm{b}}$ & $65.17 \pm 4.75^{\mathrm{b}}$ & $52.33 \pm 3.23^{\mathrm{b}}$ & $42.17 \pm 2.64^{\mathrm{b}}$ \\
Motility & & & & \\
CG & $70.50 \pm 3.08^{\mathrm{c}}$ & $56.17 \pm 4.49^{\mathrm{c}}$ & $45.50 \pm 5.24^{\mathrm{c}}$ & $43.50 \pm 5.24^{\mathrm{c}}$ & $38.23 \pm 3.50^{\mathrm{c}}$ \\
T1 & $87.33 \pm 3.45^{\mathrm{a}}$ & $76.83 \pm 4.23^{\mathrm{a}}$ & $69.83 \pm 7.22^{\mathrm{a}}$ & $57.17 \pm 6.08^{\mathrm{a}}$ & $46.53 \pm 3.08^{\mathrm{a}}$ \\
T2 & $80.50 \pm 2.17^{\mathrm{b}}$ & $70.50 \pm 3.50^{\mathrm{b}}$ & $62.17 \pm 4.75^{\mathrm{b}}$ & $50.33 \pm 3.23^{\mathrm{b}}$ & $41.17 \pm 2.64^{\mathrm{b}}$ \\
\hline
\end{tabular}

Values with different superscripts in the same column of viability and motility variable are significantly different $(p<0.05)$. $\mathrm{CG}=$ Control Group, T1 and T2 diluted semen supplemented with L-arginine at 4 and $6 \mathrm{mM}$, respectively

Table-3: Effect of L-arginine addition in skim milk extender chilled for a 5-day evaluation on the number of motile goat spermatozoa.

\begin{tabular}{lccccc}
\hline Group & Day 1 & Day 2 & Day 3 & Day 4 & Day 5 \\
\hline CG & $7041.19 \pm 307.62$ & $5609.98 \pm 448.44$ & $4544.31 \pm 523.35$ & $4344.56 \pm 523.35$ & $3818.22 \pm 349.56$ \\
& $(56 / 0.44)$ & $(45 / 0.56)$ & $(36 / 0.69)$ & $(35 / 0.72)$ & $(31 / 0.82)$ \\
T1 & $8722.08 \pm 344.57$ & $7673.40 \pm 422.47$ & $6974.27 \pm 721.10$ & $5709.85 \pm 607.24$ & $4647.18 \pm 307.62$ \\
& $(70 / 0.36)$ & $(61 / 0.41)$ & $(56 / 0.45)$ & $(46 / 0.55)$ & $(37 / 0.67)$ \\
T2 & $8039.94 \pm 216.73$ & $7041.19 \pm 349.56$ & $6209.23 \pm 474.41$ & $5026.71 \pm 322.60$ & $4111.85 \pm 263.67$ \\
& $(64 / 0.39)$ & $(56 / 0.44)$ & $(50 / 0.50)$ & $(40 / 0.62)$ & $(33 / 0.76)$ \\
\hline
\end{tabular}

The numbers in brackets are the average of the doses with 125 million motile sperm cells for intracervical insemination/volume in $\mathrm{ml}$ 
Table-4: Effect of L-arginine addition in skim milk extender chilled for a 5-day evaluation on the intactness of the plasma membrane (IPM) and the MDA level $(\mathrm{nmol} / \mathrm{ml})$ of goat spermatozoa.

\begin{tabular}{cccccc}
\hline Parameters & Day 1 & Day 2 & Day 3 & Day 4 & Day 5 \\
\hline IPM & & & & & \\
CG & $53.00 \pm 2.83^{\mathrm{c}}$ & $45.33 \pm 2.16^{\mathrm{c}}$ & $35.07 \pm 2.87^{\mathrm{c}}$ & $20.83 \pm 2.79^{\mathrm{c}}$ & $15.83^{\mathrm{a}} \pm 2.63^{\mathrm{c}}$ \\
T1 & $68.00 \pm 2.10^{\mathrm{a}}$ & $56.53 \pm 2.31^{\mathrm{a}}$ & $49.33 \pm 2.25^{\mathrm{a}}$ & $35.67 \pm 2.50^{\mathrm{a}}$ & $22.67 \pm 1.63^{\mathrm{a}}$ \\
T2 & $57.08 \pm 2.16^{\mathrm{b}}$ & $50.50 \pm 3.27^{\mathrm{b}}$ & $41.50 \pm 2.33^{\mathrm{b}}$ & $22.17 \pm 2.17^{\mathrm{b}}$ & $18.83 \pm 3.72^{\mathrm{b}}$ \\
MDA & & & & \\
CG & $2305.25 \pm 52.83^{\mathrm{c}}$ & $2510.35 \pm 32.16^{\mathrm{c}}$ & $2805.17 \pm 42.87^{\mathrm{c}}$ & $3490.17 \pm 22.79^{\mathrm{c}}$ & $3876.17 \pm 42.25^{\mathrm{c}}$ \\
T1 & $1636.43 \pm 42.39^{\mathrm{a}}$ & $1786.34 \pm 12.31^{\mathrm{a}}$ & $2056.45 \pm 32.25^{\mathrm{a}}$ & $2375.35 \pm 42.50^{\mathrm{a}}$ & $2850.25 \pm 31.23^{\mathrm{a}}$ \\
T2 & $1845.34 \pm 32.17^{\mathrm{b}}$ & $2095.45 \pm 33.27^{\mathrm{b}}$ & $2563.24 \pm 32.10^{\mathrm{b}}$ & $2945.35 \pm 52.20^{\mathrm{b}}$ & $3245.25 \pm 23.45^{\mathrm{b}}$ \\
\hline
\end{tabular}

Values with different superscripts in the same column of IPM and MDA variables are significantly different $(p<0.05)$.

$\mathrm{CG}=$ Control group, $\mathrm{T} 1$ and $\mathrm{T} 2$ diluted semen supplemented with L-arginine at 4 and $6 \mathrm{mM}$, respectively,

MDA=Malondialdehyde, IPM: Intact plasma membrane

Table-5: Effect of L-arginine addition in skim milk extender chilled for a 5-day evaluation on the necrosis and apoptosis (\%) of goat spermatozoa.

\begin{tabular}{lccccc}
\hline Treatment & Day 1 & Day 2 & Day 3 & Day 4 & Day 5 \\
\hline Necrosis & & & & & \\
CG & $18.83 \pm 3.82^{\mathrm{c}}$ & $26.50 \pm 2.33^{\mathrm{c}}$ & $29.05 \pm 1.86^{\mathrm{c}}$ & $35.17 \pm 2.71^{\mathrm{c}}$ & $39.17 \pm 2.76^{\mathrm{c}}$ \\
T1 & $5.67 \pm 3.50^{\mathrm{a}}$ & $8.17 \pm 3.43^{\mathrm{a}}$ & $15.50 \pm 1.14^{\mathrm{a}}$ & $20.50 \pm 4.23^{\mathrm{a}}$ & $23.33 \pm 2.41^{\mathrm{a}}$ \\
T2 & $16.50 \pm 1.76^{\mathrm{b}}$ & $20.00 \pm 2.89^{\mathrm{b}}$ & $22.83 \pm 2.87^{\mathrm{b}}$ & $25.33 \pm 3.88^{\mathrm{b}}$ & $29.50 \pm 3.15^{\mathrm{b}}$ \\
Apoptosis & & & & \\
CG & $17.83 \pm 3.62^{\mathrm{c}}$ & $25.50 \pm 2.33^{\mathrm{c}}$ & $29.05 \pm 1.76^{\mathrm{c}}$ & $36.15 \pm 2.71^{\mathrm{c}}$ & $39.27 \pm 2.76^{\mathrm{c}}$ \\
T1 & $7.67 \pm 3.50^{\mathrm{a}}$ & $9.17 \pm 3.43^{\mathrm{a}}$ & $15.50 \pm 1.14^{\mathrm{a}}$ & $21.50 \pm 4.23^{\mathrm{a}}$ & $24.33 \pm 2.21^{\mathrm{a}}$ \\
T2 & $12.50 \pm 1.76^{\mathrm{b}}$ & $20.00 \pm 2.59^{\mathrm{b}}$ & $22.83 \pm 2.37^{\mathrm{b}}$ & $25.33 \pm 3.68^{\mathrm{b}}$ & $29.50 \pm 3.15^{\mathrm{b}}$ \\
\hline
\end{tabular}

Values with different superscripts in the same column as the necrosis and apoptosis variables are significantly different $(p<0.05) . C G=$ Control group, T1 and T2 diluted semen supplemented with L-arginine at 4 and 6 mM, respectively

role in the absorption of oxygen for cell metabolism and increases sperm motility [16], and helps induce acrosome reactions, sperm chemotaxis, and spermegg interaction $[17,18]$. Low doses of L-arginine induce glucose metabolism, high consumption of substrate, and finally impact higher sperm motility (T1 of Table-2) and prevent lipid peroxidation [19]. In contrast, high L-arginine concentration reduces sperm motility [16,17] and adversely affects the quality of spermatozoa in long-term storage, as shown in T2 of Table-2 [14].

The decrease in temperature and duration of storage causes a reduction in the viability and motility of spermatozoa mediated to biochemical changes by cold shock, osmotic disorders, and cell membrane damage due to oxidative stress [20]. In the process of mitochondrial oxidative phosphorylation, nicotinamide adenine dinucleotide is an electron donor, and oxygen is an electron acceptor in the electron transport chain. The process is an oxidation and reduction reaction in the synthesis of adenosine triphosphate [21], energy for sperm motility. The electrophilic aldehydes generated as a result of lipid peroxidation leads to a rapid loss of sperm motility [22].

The ROS plays a role in regulating sperm function and fertilization [23]. Physiologically, ROS is essential for regular purposes of spermatozoa, such as maturation, hyperactivation, acrosome reaction, and spermatozoa-oocyte fusion [24]. In viable and fertile sperm, both in fresh and diluted semen, ROS levels, and membrane lipid peroxidation are low [25]. At low levels, ROS plays a decisive role in tyrosine phosphorylation, sterol oxidation, and cholesterol efflux from the plasma membrane in the spermatozoon capacitation and the fertilization process [26].

A dose of 125 million motile spermatozoa was optimum for goat and ewes' intracervical insemination $[27,28]$. In this study, the supplementation of $4 \mathrm{mM}$ L-arginine in the skim milk extender (T1) had the most amount of motile spermatozoa, although, on the $5^{\text {th }}$ day of storage at $5^{\circ} \mathrm{C}$, it was viable for 37 doses of intracervical insemination, with $<1 \mathrm{ml}$ volume per dose.

\section{IPM and malondialdehyde level}

Intact, the plasma membrane (IPM) has a negative correlation to MDA and is positively correlated with the viability and motility of spermatozoa. The low dose of L-arginine results in higher viability and motility of spermatozoa; mediated, it increases the antioxidant capacity of semen, which results in a decrease in MDA [29].

The lipid of goat sperm's plasma membrane has a higher concentration of unsaturated fatty acids compared to other ruminants. Therefore, in the chilling process, the lipid of the plasma membrane can be damaged, resulting in lipid peroxidation. Susceptibility to cold temperatures is associated with a higher ratio of unsaturated fatty acids than saturated fats, which results in the formation of a highly ROS [30]. One of the products of lipid peroxidation is MDA [26], which increases in long-term storage. 


\section{Necrosis and apoptosis}

Necrosis and apoptosis of spermatozoa seemed positive correlated with MDA level, and negatively correlated with viability, motility, and IPM. Necrosis is acute and irreversible cell death, caused by the inability of the cells to adapt. Due to the damage to the plasma membrane, it is unable to maintain the homeostasis that allows the entry of water and extracellular ions [31]. Cell necrosis may occur due to the activity of lysozyme, an enzyme product of lysosome. It digests the cell membranes such as the mitochondria membrane, ribosomes, and other cell apparatus, including intracytoplasmic fluid so that damage is caused to the cells, followed by cell lysis [32].

Apoptosis is a programmed cell death that is not preceded by cell swelling or inflammation. Apoptotic cells will shrink due to a breakup of the cell nucleus and the chromosomes, which all form apoptotic bodies. The apoptosis is triggered by lipid peroxidation, which leads to the activation of ROS in a continuous redox cycle. This cascade also includes the increased activity of a p53 protein, which will activate the Bax protein and then stimulate mitochondria to produce excessive cytochrome $\mathrm{c}$ that will cause apoptosis [32]. Cytochrome c is made up of apoptogenic proteins, such as the apoptosis-inducing factor and the endonuclease $G$ [33], which cause a rapid decrease of sperm motility followed by caspase activation and exposure to phosphatidylserine on the surface of sperm a few hours later [34].

The nuclear DNA suffers oxidative damage during the chilling process, caused, among others, by the unique physical architecture of the spermatozoa and the limited cytoplasmic capacity that these cells possess for DNA repair. There was a correlation between the activation of caspase-3, an increased DNA fragmentation, and the lower fertilization rates of in vitro fertilization $[35,36]$. Damage of the DNA integrity of sperm during the chilling process is also related to the ROS [37].

The percentage of necrosis and apoptosis will be increased each day of storage, caused by the spermatozoa not being able to adapt to the changing composition of the extender. Simultaneously in the process of chilling, ROS increased, which affected the damage of DNA, especially the integrity of DNA as a cause of cell death [38]. The addition of L-arginine in low doses resulted in the lowest percentage of necrosis and apoptosis.

\section{Conclusion}

The addition of $4 \mathrm{mM} \mathrm{L}$-arginine in skim milk extender, which is stored in chilled temperature, maintains goat spermatozoa in the best quality (viability, motility, and IPM) as it inhibits elevation of MDA level, the percentage of necrosis and apoptosis of the spermatozoa. An ejaculate in this extender could be divided into 37 doses for intracervical insemination in $<1 \mathrm{ml}$ volume with 125 million motile spermatozoa.

\section{Authors' Contributions}

The SS compiled ideas and designed the main framework of this text as a part of research work under the supervision of IM and PS. SS and INT processed and evaluated the chilling of diluted goat semen. AA processed the measurement of MDA levels and staining for sperm necrosis and apoptosis. SS and WW conducted statistical analysis and conceived the manuscript. IM and PS critically read and revised the manuscript for intellectual content. All the authors read and approved the final manuscript.

\section{Acknowledgments}

This research was supported by funding from the Directorate General of Higher Education, Ministry of Research, Technology and Higher Education (RISTEK-DIKTI), Republic of Indonesia, Grant number: 122/SP/PTNBH/DRPM/2018. The authors are also grateful to all of the laboratory staff in the Department of Reproduction, Faculty of Veterinary Medicine, Universitas Airlangga.

\section{Competing Interests}

The authors declare that they have no competing interests.

\section{Publisher's Note}

Veterinary World remains neutral with regard to jurisdictional claims in published institutional affiliation.

\section{References}

1. Lessard, C., Parent, S., LeClerc, P., Bailey, J.L. and Sullivan, R. (2000) Cryopreservation alters the levels of the bull sperm surface protein P25b. J. Androl., 21(5): 700-707.

2. Macías, A., Ferrer, L.M., Ramos, J.J., Lidón, I., Rebollar, R., Lacasta, D. and Tejedor, M.T. (2017) Technical note: A new device for cervical insemination of sheep-design and field test. J. Anim. Sci., 95(12): 5263-5269.

3. Faigl, V., Vass, N., Jávor, A., Kulcsár, M., Solti, L., Amiridis, G. and Cseh, S. (2012) Artificial insemination of small ruminants a review. Acta Vet. Hung., 60(1): 115-129.

4. Dwinofanto, H., Rimayanti, R., Mustofa, I., Susilowati, S. and Hernawati, T. (2018) The effect of duration of preservation on the quality, MDA level, and DNA damage of post-thawed Bali cattle bull sperm. Iraqi J. Vet. Sci., 32(2): 249-252.

5. Kumaresan, A., Kadirvel, G., Bujarbarbaruah, K.M., Bardoloi, R.K., Das, A., Kumar, S. and Naskar, S. (2009) Preservation of boar semen at $18^{\circ} \mathrm{C}$ induced lipid peroxidation and apoptosis-like changes in spermatozoa. Anim. Reprod. Sci., 110(1-2): 162-171.

6. Am-in, N., Tantasuparuk, W., Manjarin, R. and Kirkwood, R.N. (2011) Effect of site of sperm deposition on fertility when sows are inseminated with aged semen. $J$. Swine Health Prod., 19(5): 295-297.

7. Susilowati, S., Sardjito, T., Widodo, O.S., Kurnijasanti, R., Wurlina, W., Safitri, E. and Mustofa, I. (2018) Effect of green tea extract addition in the semen extender on postthaw sperm quality of Simmental bulls. Philipp. J. Vet. Med., 55(2): 127-134.

8. Asia, P.D., Susilowati, S., Bijanti, R., Madyawati, S.P., Hernawati, T. and Restiadi, T.I. (2017) The effect of the addition of seminal plasma Simmental bull on motility and viability of fat-tailed sheep spermatozoa after equilibration 
in the freezing process. Ovozoa, 6(1): 50-54.

9. Ramu, S. and Jeyendran, R.S. (2013) The hypo-osmotic swelling test for the evaluation of sperm membrane integrity. Methods Mol. Biol., 927: 21-25.

10. Mulyati, S., Darmasasmita, D.E. and Arimbi, A. (2016) The effect of thawing length on the motility and necrosis of spermatozoa Simmental bull. Ovozoa, 5(1): 13-20.

11. Ortega-Ferrusola, C., Anel-López, L., Martín-Muñoz, P., Ortíz-Rodríguez, J.M., Gil, M.C., Alvarez, M., de Paz, P., Ezquerra,L.J., Masot,A.J., Redondo,E.,Anel,L.andPeña,F.J. (2017) Computational flow cytometry reveals that cryopreservation induces spermatosis, but subpopulations of spermatozoa may experience capacitation-like changes. Reproduction, 153(3): 293-304.

12. Korkmaz,M.K.,Emsen,E.,Köker,A. andKocamüftüoğlu,M. (2017) The duration effect of fresh semen kept in vitro on sheep conception rate. Anim. Reprod., 14(4): 1147-1150.

13. Bibov, M.Y., Kuzmin, A.V., Alexandrova, A.A., Chistyakov, V.A., Dobaeva, N.M. and Kundupyan, O.L. (2018) Role of the reactive oxygen species induced DNA damage in human spermatozoa dysfunction. AME Med. J., 3(19): 1-12.

14. Kaya, S.O., Gür, S. and Kaya, E. (2017) Effect of L-arginine addition on long-term storability of ram semen. Andrologia, 50: $1-5$.

15. Oyeyipo, I.P., Raji, Y. and Bolarinwa, A.F. (2015) Nitric oxide synthase inhibition ameliorates the nicotine-induced sperm function decline in male rats. Asian Pac. J. Reprod., 4(3): 212-216.

16. Maidin, M.S., Adanan, N.F., Aminudin, M.T. and Tawang, A. (2014) In vitro supplements improve motility and the progressive score of spermatozoa in Jermasia goats. APCBEE Procedia, 8(2014): 329-333.

17. El-Shahat, K.H., Taysser, M.I., Badr, M.R. and Zaki, K. (2016) Effect of L-arginine treatment on motility, hyperactivity, and acrosome reaction of ejaculated ram spermatozoa. Anim. Reprod., 13(2): 75-80.

18. Garg, V. and Garg, S.P. (2011) Review paper: Role of nitric oxide in male infertility. $J$. Indian Acad. Forensic Med., 33(1): 65-68.

19. Srivastava, S., Prashant, D., Evans, C. and Girjesh, G. (2006) Mechanism of action of L-arginine on the vitality of spermatozoa is primarily through increased biosynthesis of nitric oxide. Biol. Reprod., 74(5): 954-958.

20. Sariozkan, S., Turk, G., Canturk, F., Yay, A., Eken, A. and Akcay, A. (2013) The effect of bovine serum albumin and fetal calf serum on sperm quality, DNA fragmentation, and lipid peroxidation of the liquid stored rabbit semen. Cryobiology, 67(1): 1-6.

21. Wagner, H., Cheng, J.W. and Ko, E.Y. (2018) Role of reactive oxygen species in male infertility: An updated review of the literature. Arab J. Urol., 16(1): 35-43.

22. Aitken, R.J. and Baker, M.A. (2013) Causes and consequences of apoptosis in spermatozoa: Contributions to infertility and impacts on development. Int. J. Dev. Biol., 57(2-4): 265-272.
23. Aitken, R.J., Jones, K.T. and Robertson, S.A. (2012) Review: Reactive oxygen species and sperm function in sickness and in health. J. Androl., 33(6): 1096-1106.

24. Turk, G. (2015) Physiological and Pathological Effects of Reactive Oxygen Species on Spermatozoon Functions. Telecom Regulatory Authority of India, New Delhi. p26-34.

25. Guthrie, H.D. and Welch, G.R. (2012) Effects of reactive oxygen species on sperm function. Theriogenology, 78(8): $1700-1708$

26. Takeshima, T., Kuroda, S. and Yumura, Y. (2018) Reactive Oxygen Species and Sperm Cells. Ch. 6. InTech, Budapest.

27. Mustofa, I., Hermadi, H.A., Srianto, P., Sardjito, T., Suprayogi, T.W., Samik, A. and dan Dewi, E.I.K. (1998) Efforts to increase local sheep fertility with superovulation techniques using low-dose of PMSG. Vet. Med. J., 14(1): 18-23.

28. Mustofa, I. (2005) Effectivity of estrous synchronization on ewes when using Prostaglandin $\mathrm{F}_{2 \alpha}\left(\mathrm{PGF}_{2 \alpha}\right)$ intrauterine compared to intramuscular administration. Vet. Med. J., 21(3): 123-126.

29. Chen, J.Q., Li, Y.S., Li, Z.J., Lu, H.X., Zhu, P.Q. and Li, C.M. (2018) Dietary L-arginine addition improves semen quality and the libido of boars under high ambient temperature. Animal, 12(8): 1611-1620.

30. Bansal, A.K. and Bilapuri, G.S. (2011) Impacts of oxidative stress and antioxidants on semen functions. Vet. Med. Int., 2011: Article ID 686137.

31. Edinger, A.L. and Thompson, C.B. (2004) Death by design: Apoptosis, necrosis, and autophagy. Curr. Opin. Cell Biol., 16(6): 663-669.

32. Andrew, W.D., Hill, V.D., Keesey, J. and Manzow, S. (2002) Cell Death Apoptosis and Necrosis Proliferation. Boehringer, Mannheim.

33. Li, L.Y., Luo, X. and Wang, X. (2001) Endonuclease G is an apoptotic DNase when released from mitochondria. Nature, 412(6842): 95-99.

34. Peterson, Q.P., Goode, D.R., West, D.C., Botham, R.C. and Hergenrother, P.J. (2010) Preparation of the caspase $-3 / 7$ substrate AC-DEVD-pNA by solution-phase peptide synthesis. Nat. Protoc., 5(2): 294-302.

35. Manente, L., Pecoraro, S., Picillo, E., Gargiulo, U., Gargiulo, P., De Luca, A. and Politano, L. (2015) Molecular evidence of apoptotic pathway activation in semen samples with high DNA fragmentation. In Vivo, 29(2): 289-294.

36. Zorn, B., Golob, B., Ihan, A., Kopitar, A. and Kolbezen, M. (2012) Apoptotic sperm biomarkers and their correlation with conventional sperm parameters and male fertility potential. J. Assist. Reprod. Gen., 29(4): 357-364.

37. Gürler, H., Malama, E., Heppelmann, M., Calisici, O., Leiding, C., Kastelic, J.P. and Bollwein, H. (2016) Effects of cryopreservation on sperm viability, synthesis of reactive oxygen species, and DNA damage of bovine sperm. Theriogenology, 86(2): 562-571.

38. Aitken, R.J. and Krausz, C. (2001) Oxidative stress, DNA damage, and the Y chromosome. Reproduction, 122(4): 497-506. 